\title{
DO ALERTA À AÇÃO: DISCURSOS SOBRE A EPIDEMIA DO ZIKA NO JORNAL DIARIO DE PERNAMBUCO
}

\author{
FROM ALERT TO ACTION: DISCOURSES ON THE ZIKA OUTBREAK IN THE \\ BRAZILIAN DAILY NEWSPAPER DIARIO DE PERNAMBUCO \\ DE ALERTA A ACCIÓN: DISCURSOS SOBRE LA EPIDEMIA DE ZIKA EN EL \\ DIARIO DE PERNAMBUCO
}

\section{Natalia Martins Flores' \\ Isaltina Maria de Azevedo Mello Gomes²}

RESUMO: Analisamos a construção discursiva da epidemia do Zika vírus no Brasil (2015-2016) no jornal Diario de Pernambuco. Nossa questão norteadora consiste em compreender quais as posturas assumidas pelo jornal na discursivização da epidemia, desvelando atores discursivos e efeitos de sentido produzidos sobre o surto. A partir do aporte da Análise do Discurso, analisamos 210 títulos de notícias publicadas no site do jornal entre outubro de 2015 e abril de 2016. Classificamos o corpus em cinco categorias comunicativas: Alerta (35\%), Ação (32\%), Convicção científica (24\%), Orientação (5\%)e Consequências (4\%). A maioria dos enunciados mobiliza discursos oficiais, institucionais e científicos sobre a epidemia, ora representando-a como um evento extraordinário, com expansão alarmante, ora minimizando os seus efeitos. O foco principal está nas ações das autoridades e dos cientistas na contenção do avanço da epidemia.

Palavras-chave: Zika vírus. Cobertura jornalística. Construção discursiva.

ABSTRACT: We analyzed the discursive construction of the Zika virus outbreak in Brazil (2015-2016) in the newspaper Diario de Pernambuco. Our guiding question

ORCID: 0000-0001-9687-9686/E-mail: nataliflores@gmail.com

2 ORCID: 0000-0003-2256-8564. E-mail: isaltina@gmail.com 
is to understand the postures assumed by the newspaper in the discursivization of the outbreak, revealing discursive actors and meaning effects produced on the issue. Based on the contribution of Discourse Analysis, we analyzed 210 titles of news published on the newspaper's website between October 2015 and April 2016. We classified the corpus into five communicative categories: Alert (35\%), Action (32\%), Scientific Conviction (24\%), Orientation (5\%) and Consequences (4\%). Most of the enunciations mobilize official, institutional and scientific discourses on the outbreak, sometimes representing it as an extraordinary event, with alarming expansion, sometimes minimizing its effects. The main focus is on the actions of the authorities and scientists in containing the spread of the outbreak.

Keywords: Zika virus. News coverage. Discursive construction.

RESUMEN: Analizamos la construcción discursiva de la epidemia del Zika virus en Brasil (2015-2016) en el periódico Diario de Pernambuco. Nuestra cuestión orientadora consiste en comprender cuáles son las posturas asumidas por el periódico en la discursivización de la epidemia, desvelando actores discursivos y efectos de sentido producidos sobre el tema. A partir del aporte del Análisis del Discurso, analizamos 210 títulos de noticias publicadas en el sitio del periódico entre octubre de 2015 y abril de 2016. Clasificamos el corpus en cinco categorías comunicativas: Alerta (35\%), Acción (32\%), Convicción científica (24\%), Orientación (5\%) y Consecuencias (4\%). La mayoría de los enunciados moviliza discursos oficiales, institucionales y científicos sobre la epidemia, ora representándola como un evento extraordinario, con expansión alarmante, o minimizando sus efectos. El foco principal está en las acciones de las autoridades y de los científicos en la contención del avance de la epidemia.

Palavras-clave: Zíka Vírus. Cobertura periodística. Construcción discursiva.

\section{Introdução}

O Zika Vírus, que começou a circular no território americano em meados de 2014 e teve seu primeiro caso registrado no Brasil em 2015, se disseminou rapidamente em boa parte dos países das Américas, passando a chamar a atenção de autoridades de saúde internacionais e da mídia. A principal causa de preocupação era a possível relação do vírus com casos de microcefalia em bebês , confirmada pelo Ministério da Saúde (MS) em novembro de 2015. Essa conjuntura levou a Organização Mundial da Saúde (OMS) a decretar estado de Emergência de Saúde Pública de Importância Internacional (ESPII), em $1^{\circ}$ de fevereiro de 2016 
- O perfil de risco do Zika passou, então, de uma leve ameaça a uma epidemia de proporções alarmantes.

No território nacional, a epidemia do Zika Vírus produziu uma intensa mobilização do Ministério da Saúde e de autoridades governamentais, com o lançamento de campanhas nacionais de combate ao mosquito Aedes aegypti, vetor transmissor da doença. Somado a isso, houve também uma intensa cobertura jornalística nos jornais e nos noticiários de televisão de Pernambuco, estado onde a epidemia começou e atingiu maior importância. Em situações epidêmicas, jornais locais podem ser potenciais aliados das autoridades públicas no enfrentamento da epidemia, por meio da disseminação de informações sobre o vírus e sobre estratégias de eliminação de focos do mosquito.

Partindo dessa perspectiva, neste artigo analisamos o modo como o jornal Diario de Pernambuco construiu discursivamente a epidemia do Zika vírus. Diante do cenário epidêmico, interessa-nos compreender qual a postura assumida pelo jornal no decorrer da epidemia. Temos interesse em destrinchar quais foram os discursos, atores discursivos e efeitos de sentido sobre a epidemia mobilizados por sua produção discursiva. Nos focamos na análise de 210 títulos de matérias jornalísticas publicadas no site do jornal nos meses de outubro de 2015 a abril de 2016. Balizamos nossa análise no aporte teórico-metodológico da Análise do Discurso, mobilizando conceitos como efeitos de sentido, funções comunicativas e atores discursivos.

\section{Discursos jornalísticos sobre epidemias}

Nos últimos anos, diversos estudos do campo da comunicação e saúde se interessaram por analisar a cobertura midiática feita em contextos de epidemia. Alguns estudos adotaram uma perspectiva de análise longitudinal, focando-se em entender em que momentos a mídia acentua a cobertura sobre doenças infecciosas específicas (SHIH; WIJAYA; BROSSARD, 2008; FERRAZ; GOMES, 2012). Outros avaliaram a cobertura da saúde em um determinado veículo (FONSECA; GOMES, 2015) ou adotaram um recorte mais específico, focando-se na cobertura midiática feita por um veículo sobre um cenário epidêmico particular, como a gripe espanhola (FARIAS, 2008), o surto da dengue, em 2002 (FERRAZ; GOMES, 2012), a gripe aviária, em 2008, (MEDEIROS; MASSARANI, 2010; 2011a; 2011b; LERNER; GRADELLA, 2011) e a epidemia do vírus da Zika, em 2015 (AGUIAR; ARAÚJO, 2016; PRAZERES; LIMA; MACIEL, 2016; GOMES, SILVA; FEITOZA, 2018). 
Shih, Wijaya e Brossard (2008) compararam a construção de narrativas no jornal New York Times sobre as epidemias da doença da vaca louca, do vírus do West Nile e da gripe aviária em notícias publicadas em um período de 10 anos. Segundo sua análise, os enquadramentos escolhidos pela mídia mudam conforme os estágios do ciclo das epidemias. A cobertura desses temas, nesse período, foi baseada em eventos pontuais, como os anúncios de novos casos de infectados e as ações governamentais para conter a epidemia, diferenciando-se do modo como outros temas científicos são tratados na mídia. Por serem baseadas em eventos, eles salientam, ainda, que o desaparecimento de notícias sobre epidemias não significa, necessariamente, que o problema tenha sido resolvido.

A orientação da cobertura de doenças por eventos específicos também é salientada por Ferraz e Gomes (2012) em estudo sobre a cobertura da dengue feita pelo Jornal do Commercio, de Pernambuco. A análise das notícias veiculadas em períodos de epidemia (2002, 2004, 2006 e 2008) e de endemia do vírus mostraram que as coberturas priorizam os momentos de epidemia, transformando a dengue em um fenômeno midiático. Isso ocorre devido a esse cenário de alarme público satisfazer o agendamento da imprensa e os valores jornalísticos de imprevisibilidade, novidade e singularidade. É no momento da epidemia que a doença tem maior capacidade de afetar o ecossistema da saúde e a rotina das cidades, transformando-se em matéria-prima para o jornalismo (FERRAZ; GOMES, 2012).

As notícias sobre epidemia mobilizam uma série de sentidos sobre epidemias, acionadas na leitura desses enunciados. Os efeitos de sentido são entendidos, aqui, como produtos do discurso que se colocam em relação às produções e interpretações dos locutores, afetadas pela língua e pela história (ORLANDI, 2002). O jornalismo, em particular, ocupa um lugar privilegiado de produção e circulação de sentidos, reconstruindo fatos do mundo através do seu discurso (BENETTI, 2006). Esse funcionamento pode ser observado no caso da cobertura jornalística sobre a dengue, analisada por Ferraz e Gomes (2012; 2015). Uma rede de memórias compartilhadas e sentimentos de doenças foi mobilizada, como o medo, o mal, o perigo, a morte e a peste.

A construção discursiva em torno de sentidos alarmantes parece ser comum à cobertura de epidemias em veículos impressos e noticiários televisivos, reproduzidas no meio digital. As análises da cobertura da epidemia da gripe A/ $\mathrm{H}_{1} \mathrm{~N}_{1}$, em 2009, no Jornal Nacional (MEDEIROS; MASSARANI, 2010; 2011a) e no Fantástico (MEDEIROS; MASSARANI, 2011b) e nos jornais impressos cariocas $O$ Globo e O Dia (LERNER; GRADELLA, 2011) mostram que esses veículos optaram por uma construção de sentidos de medo e preocupação em torno da doença, 
gerando o que Medeiros e Massarani (2010; 2011a) nomeiam de "pandemia do pânico". No Jornal Nacional, por exemplo, deu-se destaque sobre os números de infectados, capazes de gerar pânico no público ao invés de se explorar informações sobre pesquisas científicas para combater a epidemia (MEDEIROS; MASSARANI, 2011a). Segundo Lerner e Gradella (2011), a mobilização do medo nos jornais impressos cariocas serviu tanto para cobrar do poder público medidas para o enfrentamento da pandemia quanto para desqualificar as mesmas autoridades.

A cobertura midiática da epidemia do Zika foi analisada por Aguiar e Araújo (2016) e Prazeres, Lima e Maciel (2016). Aguiar e Araújo (2016) delinearam uma linha do tempo dos eventos discursivos do vírus, relacionando os anúncios oficiais sobre o tema e a cobertura feita pela mídia. Elas observaram um forte efeito de agendamento entre os anúncios do Ministério da Saúde e os jornais, acompanhada de matérias desconectadas desses anúncios, produzidas pelos próprios veículos. Além disso, a análise de nove capas de jornais brasileiros impressos publicadas nos meses de novembro e dezembro de 2015 apontou para uma narrativa construída em torno do medo e do risco - esse último associado ao anúncio de alerta de saúde pública realizado pela Organização Pan Americana da Saúde (OPAS) e ao grau de incerteza em relação a essa epidemia.

Em estudo focado em 20 edições impressas do Diario de Pernambuco, Prazeres, Lima e Maciel (2016) apontaram existir uma forte fundamentação científica, nas notícias sobre as doenças ligadas ao Aedes aegypti, com informações de fontes de instituições de pesquisa brasileiras, como a Fiocruz, e internacionais, como a OMS. Segundo as pesquisadoras, o tratamento didático das matérias demonstrou a função pedagógica desempenhada pela mídia nesse tipo de cobertura. De acordo com Gomes, Silva e Feitoza (2018), que durante dois meses (abril e maio de 2016) analisaram a cobertura do Zika vírus, na Folha de Pernambuco, faltou nesse periódico, uma abordagem mais contextual que estabelecesse a relação direta entre ciência e sociedade.

\section{Coleta e tratamento dos dados}

A nossa análise deteve-se em um corpus de 210 títulos de notícias da edição online do jornal Diario de Pernambuco. Selecionamos essas unidades digitando a palavra-chave "Zika", o nome do jornal e a data de publicação na ferramenta de pesquisa do Google. Detivemos nossa análise nos títulos, porque eles condensam a abordagem central escolhida pelo jornalista para conformar sua matéria. 
A escolha por outubro de 2015 como o mês inicial de coleta de dados deve-se ao fato de termos verificado um aumento repentino nas notícias sobre Zika no Diario de Pernambuco a partir desse mês. De outubro a novembro, a quantidade de notícias no Diario de Pernambuco (Figura 1) cresceu de um para 19. Esse interesse foi motivado pela provável associação do vírus com a microcefalia apresentada em bebês, fato que começou a intrigar a comunidade médica brasileira em meados de outubro de 2015 (AGUIAR; ARAÚJO, 2016). A partir de maio, as notícias sobre o zika vírus começam a escassear no Diario de Pernambuco, o que permitiu definirmos abril como o mês final da coleta de dados.

Figura 1 - Quantidade de notícias sobre Zika no Diario de Pernambuco

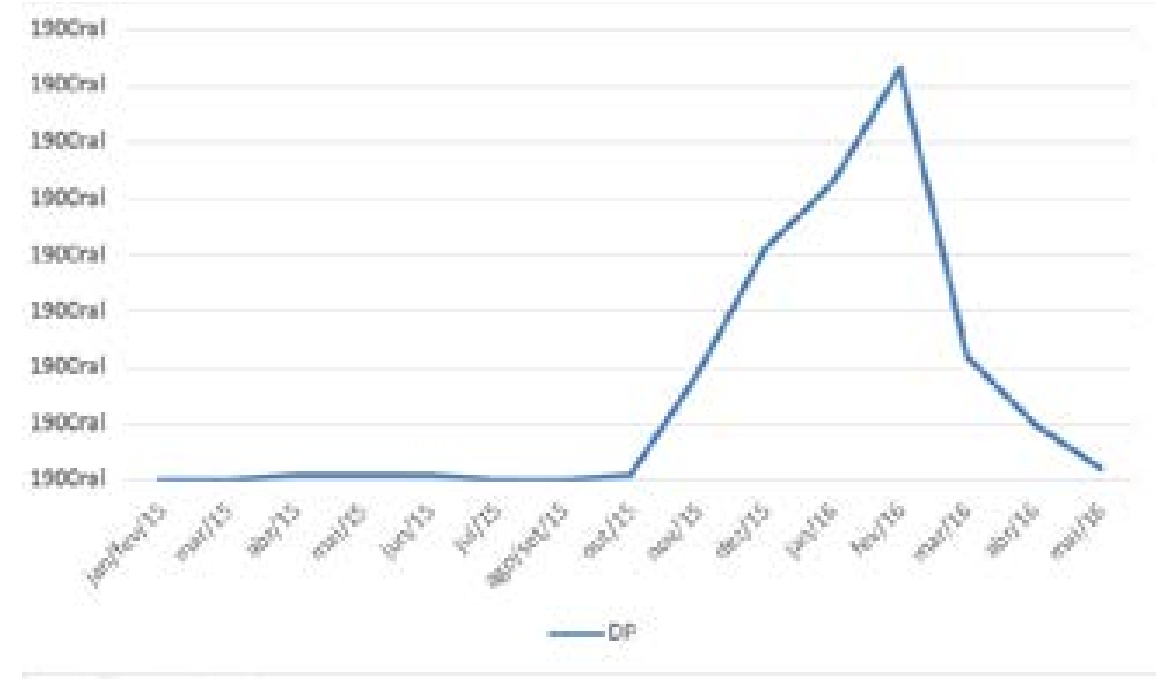

Fonte: Elaborada pelos autores.

Após construirmos o corpus de enunciados, analisamos as suas marcas textuais-discursivas. No nível micro de análise, nos focamos no tema, nos sujeitos do enunciado, nos verbos e em outras expressões utilizadas para conformar essa materialidade. Partindo da ideia de que os discursos têm uma semântica global de funcionamento que põe em relação diferentes níveis de análise (MAINGUENEAU, 2008), utilizamos as marcas textuais discursivas localizadas para mapear os atores, as matrizes discursivas e os efeitos de sentido desses enunciados. No final da análise dessas unidades lexicais, conseguimos identificar as funções comunicativas dos enunciados e elencar categorias.

A noção de função comunicativa deriva de Maingueneau (2014), que a vincula a funções sociais e discursivas da enunciação, ligadas à sua funcionalidade. Neste sentido, as funções desdobram-se em estratégias discursivas, elementos 
traçados pelo enunciador no momento da enunciação, de maneira consciente ou inconsciente (CHARAUDEAU; MAINGUENEAU, 2002). No seu conjunto, as funções de cada enunciado podem dar indicações da posição discursiva assumida pelo jornal em condições de produção específicas.

É importante salientar que o discurso é entendido como um elemento performativo destinado a agir e transformar uma dada situação. Em situações de risco epidêmico, a necessidade de agir sobre uma realidade assume proporções maiores, já que é preciso mobilizar as pessoas para conter a disseminação do vetor transmissor do vírus - pelo menos nos primeiros meses da epidemia.

Após a análise, organizamos os enunciados em cinco categorias, levando em conta a sua função comunicativa. Quantificamos o número de enunciados em cada categoria e também a recorrência dessas categorias ao longo dos meses da epidemia.

\section{Análise dos dados}

As marcas linguístico-discursivas dos enunciados construíram configurações de comunicação de risco de Alerta, Orientação, Convicção Científica, Ação e Consequências. Nomeamos essas categorias levando em conta os efeitos prováveis que os discursos querem causar no público, assim como os temas e as esferas discursivas (científica, institucional, social). Cada uma apresenta uma função comunicativa distinta e mobiliza esferas do discurso e atores específicos (Quadro 1): 
Quadro 1 - Categorias Comunicativas da cobertura do vírus da Zika

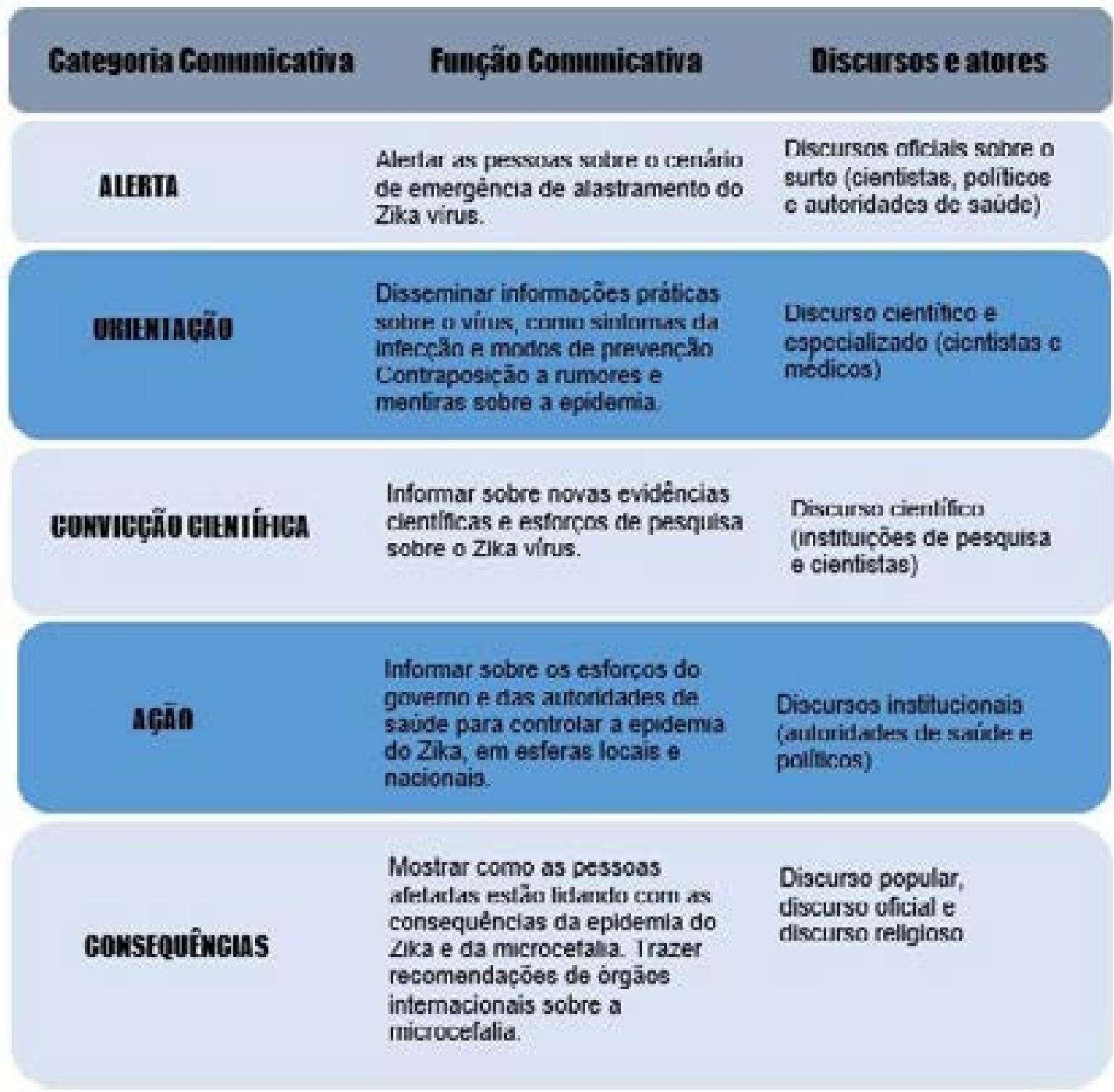

Fonte: Elaborado pelos autores.

Analisando a frequência dessas categorias comunicativas, observamos que a maior quantidade de enunciados pertence à categoria de Alerta (com 74 enunciados, ou seja, 35\% do corpus), seguida pelas categorias de Ação (com 66 enunciados, 32\%) e de Convicção Científica (50 enunciados, 24\%) (Figura 2). 0 número de enunciados cuja categoria é de Orientação é baixíssimo em relação às outras categorias ( 11 enunciados, $5 \%$ ), assim como os enunciados da categoria Consequências, representando apenas 9 ( $4 \%$ do corpus). 
Figura 2 - Quantidade de enunciados de acordo com categoria comunicativa

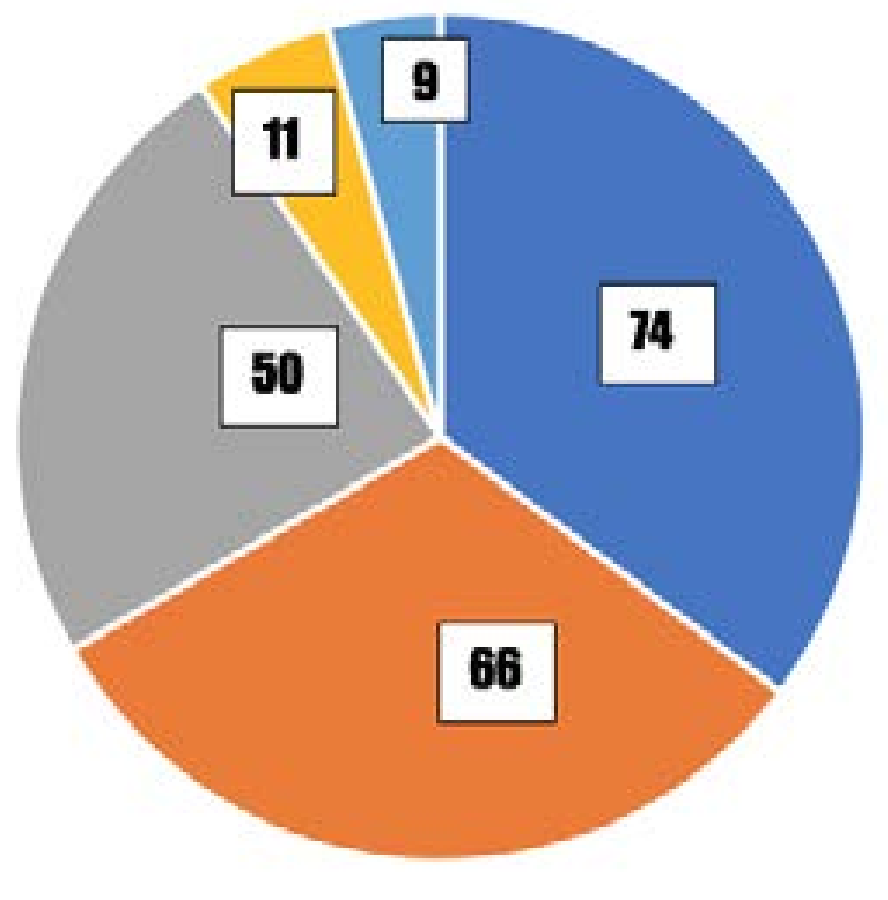

- Alerta - Açllo = Convicçăo Cientifica = Orientaç̃̃o = Consequências

Fonte: Elaborada pelos autores.

Na Figura 3 podemos observar a distribuição das categorias no decorrer dos meses analisados. As categoriais de Alerta, Convicção Científica e Ação se mantêm todos os meses, com percentagens razoáveis. O cenário de Alerta apresenta as porcentagens mais altas durante todos os meses analisados (100\%, em outubro, $53 \%$ em janeiro, $42 \%$ em março, $40 \%$ em abril e $33 \%$ em dezembro), exceto em novembro e fevereiro. Em novembro, a categoria de Convicção Científica apresentou maior percentagem de enunciados (42\%), o que pode ser explicado pela busca por explicações científicas sobre os casos eminentes de microcefalia. Em fevereiro, os enunciados de Ação têm maior frequência em comparação às outras categorias (38\%), provavelmente devido ao fato de a epidemia ter ganhado proporções internacionais nesse período, levando órgãos de saúde e grupos de pesquisa a se manifestarem e agirem na contenção da epidemia. 
Figura 3 - Percentagens das categorias no decorrer dos meses analisados

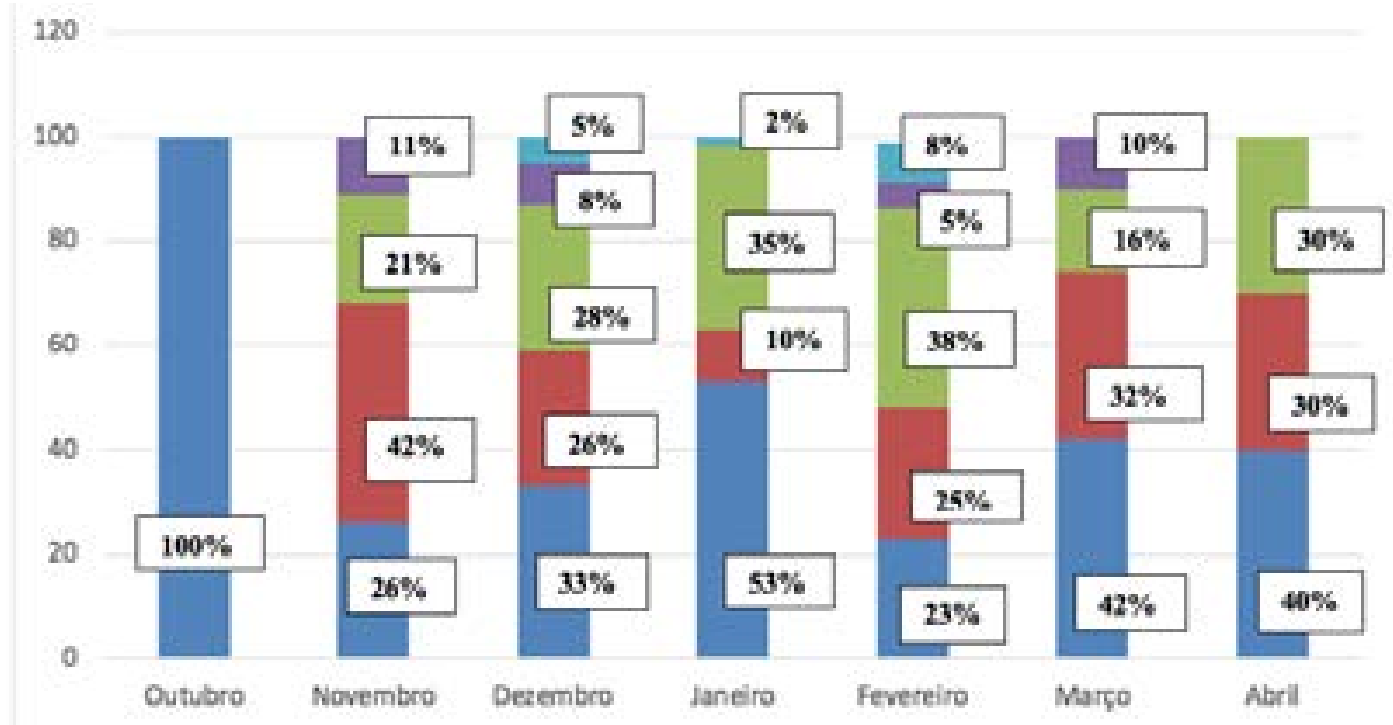

Fonte: Elaborada pelos autores.

A seguir, descrevemos as categorias identificadas e partimos para uma análise qualitativa dos enunciados do corpus.

\section{Cenário de Alerta}

A categoria comunicativa de Alerta conforma enunciados que sugerem certa urgência, construindo uma atmosfera de perigo e precaução em torno da epidemia de Zika. Os títulos relatam a chegada do vírus nos estados brasileiros e a sua disseminação para outros países. Os enunciados mobilizam discursos oficiais sobre o surto, trazendo nas suas marcas textuais discursivas declarações de autoridades de saúde e autoridades políticas para legitimar a gravidade da situação. As estratégias discursivas pendem entre o uso de uma visada emotiva e alarmista e o uso de uma visada informativa, apresentando dados concretos sobre o alastramento da epidemia. Na Figura 4, títulos exemplificam a visada alarmista: 
Figura 4 - Exemplos da categoria comunicativa de Alerta

Aumento dos casos de dengue, chikungunya e Zika leva a um estado de emergència (DP, 30/11/2015)

Ministerio da Saúde faz alerta nacional por causa do surto de microcetalia em Pemambuco (DP, 12/11/2015)

Zika virus representa uma ameaça para a saúde humana, diz instituto francês (DP, 09/01/2016)

Microcefalia: OMS decreta emergéncia de saúde pública mundial (DP, 03/02/2016)

Microcefalia leva pânico ao mundo e dá margem a novas teorias sobre suas causas (DP, 12/02/2016)

Fonte: Diario de Pernambuco.

Nos exemplos, o cenário de Alerta configura-se por meio do uso de expressões fortes e alarmistas para descrever o surto de Zika, como "estado de emergência", "alerta nacional", "ameaça" e "pânico". A estratégia discursiva desses enunciados ancorou-se na citação de declarações de fontes institucionais sobre o surto. As preocupações da Organização Mundial de Saúde (OMS), da Organização PanAmericana da Saúde (OPAS) e de um instituto francês legitimaram a construção da epidemia do Zika vírus como um evento extraordinário.

As notícias do cenário de Alerta apresentaram um crescente desde outubro, duplicando o seu valor entre janeiro e fevereiro (passando de 13 para 26 títulos com esse enquadramento). Esse aumento acompanhou o crescimento das notificações de pessoas infectadas e a disseminação global do vírus, a partir de janeiro. A escolha de um cenário de alerta também se deve aos delineamentos específicos que o surto de Zika apresenta no contexto brasileiro. Embora a comunidade científica tenha identificado o vírus pela primeira vez em 1947, este foi o primeiro surto de Zika em um país populoso. Outro fator sem precedentes apresentado por este surto foi a relação desconhecida entre microcefalia de bebês nascidos e vírus da Zika, que recém começava a ser investigada. Diante dessas circunstâncias, mulheres e mulheres grávidas foram definidas como um grupo de risco e recomendadas, pelo próprio ministro da saúde, a não viajarem para áreas epidêmicas (DIARIO DE PERNAMBUCO, 16 jan. 2016)³.

3 Disponível em: http://www.diariodepernambuco.com.br/app/noticia/brasil/2016/01/16/interna brasil,6 21865/governo-encomendara-500-mil-kits-de-testes-para-o-virus-zika.shtml. Acesso em: 27 out. 2018. 
O alarmismo é reforçado por outro conjunto de enunciados que apresentam o número das notificações no estado de Pernambuco, em outros estados e no País (Figura 5).

Figura 5 - Dados numéricos reforçam alastramento da epidemia

\section{Pernambuco tem mais de 1.600 casos de microcefalia notificados (DP, 24/02/2016)}

De 1 a 5 de janeiro estado do Rio registra 121 casos de microcefalia (DP, 06/01/2016)

Sobe para 3.893 o número de casos de microcefalia no pais (DP, 20/01/2016)

Zika está em praticamente toda a América Latina e Caribe, diz OPAS (DP, 20/01/2016)

Fonte: Diario de Pernambuco.

As marcas textuais-discursivas "mais de 1.600 casos", "Sobe para 3.8930 número de casos" e o registro de "121 casos de microcefalia", no Rio, em apenas cinco dias produzem sentidos de que a epidemia do Zika está se alastrando de maneira incontrolável. $\mathrm{O}$ uso de dados oficiais torna os enunciados mais credíveis e abarcam uma visada informativa. $O$ anúncio das notificações ocorre durante todo o período analisado e remete ao propósito do jornal em manter o seu leitor informado sobre o avanço da epidemia. O último enunciado presente nessa categoria, no mês de abril, adota um tom de prudência diante da epidemia, mostrando que, apesar do pico de notificações ter passado, a "OMS alerta que ainda é cedo para comemorar vitória sobre o zika" (DIARIO DE PERNAMBUCO, 28 abr. 2016)4.

O enquadramento discursivo do Zika Vírus como uma "ameaça" aproxima-se das construções discursivas da mídia sobre doenças infecciosas causadas por agentes biológicos. Como mostram Ferraz e Gomes (2015), no caso da dengue, a produção de significados da mídia tendeu a configurar-se em torno da ideia de perigo, mostrando-a como uma doença descontrolada. Essa abordagem repete-se na cobertura da epidemia do Zika Vírus por meio da tematização do rápido avanço da doença em todo o mundo. Além dos dados oficiais e das fontes institucionais, vozes da comunidade científica e médica são chamadas para reforçar o descontrole sobre a doença, salientando seu aspecto inédito (Figura 6).

4 AGÊNCIA ESTADO. Disponível em: https://saude.estadao.com.br/noticias/geral,oms-alerta-que-ainda-e-cedo-para-comemorar-vitoria-sobre-zika,10000034936 Acesso em: 9 out. 2019. 
Figura 6 - Manchetes exemplificam vozes de especialistas

"O que está acontecendo é inédito", diz infectologista Vicente Vaz (DP, 25/11/2015)

"É a ủnica certeza de hoje. temos de eliminar o aedes", diz pesquisador da Fiocruz (DP, 27/12/2015)

Fonte: Diario de Pernambuco.

Nos exemplos, as citações diretas são associadas a fontes especializadas que comentam o cenário de epidemia emergente. As marcas textuais discursivas "inédito" e "a única certeza de hoje" consistem em impressões e comentários delegadas a essas fontes, cuja especialidade na área da saúde traz credibilidade ao que é enunciado. Constrói-se um efeito de sentido de incerteza e ineditismo sobre a epidemia do Zika, já que até mesmo os especialistas especulam e não trazem certezas sobre o surto.

\section{Cenário Convicção Científica}

A categoria comunicativa de Convicção Científica tem como função trazer informações científicas sobre o Zika vírus. Para isso, se mobiliza o discurso científico e as vozes especializadas. Os enunciados procuram trazer o efeito de sentido de novidade e ineditismo ao enunciar: a) informações comprovadas, o que se sabe até agora sobre o vírus, b) novas descobertas e avanços científicos em relação ao assunto e c) ações de pesquisa que estão em andamento. A estratégia discursiva utilizada quando se traz informações sobre o vírus consiste em colocá-lo como protagonista principal e usar verbos que dão um efeito de sentido de precisão e certeza sobre o que está sendo enunciado ("é", "causa", "há") (Figura 7).

Figura 7 - Enunciados da categoria comunicativa Convicção Científica

Microcefalia: zika virus è a causa provável (DP, 17/11/2015)

Zika virus causa neurose cerebral (DP, 28/12/2015)

Além de sindrome de guillan-barré, há mais très doenças ligadas ao zika (DP, 30/04/2016) 
A maioria dos dados científicos sobre os casos de microcefalia vai sendo levantada no decorrer da epidemia, dando origem a descobertas sobre os modos de ação do vírus nos meses subsequentes. Por essa razão, elencamos também nesta categoria enunciados que reportam novas evidências científicas (Figura 8).

Figura 8 - Enunciados trazem evidências científicas

\section{Elo entre o zika virus e a microcetalia pode estar no cordao umbilical (DP, 11/12/2015) \\ Zika virus e capaz de atravessar a placenta das gestantes, diz Flocruz (DP, 20/01/2016)}

Flocruz confirma presença do virus zika em amostras de saliva e urina (DP, 5/02/2016)

Danos provocados por zika em bebês säo maiores do que se pensava, diz pesquisa (DP, 26/02/2016)

Fonte: Diario de Pernambuco.

Nesses casos, o tema central do enunciado continua sendo o Zika vírus e seus métodos de ação. No entanto, em alguns enunciados vemos a preocupação em incluir grupos e instituições de pesquisa como sujeitos ("diz Fiocruz, "Fiocruz confirma", "diz pesquisa"). Essas expressões juntam-se a verbos precisos ("é", "são") que relatam a descoberta científica, produzindo um efeito de sentido de que os estudos estão concluídos e têm respostas precisas sobre o surto. De outro modo, o uso da expressão verbal "pode estar" sugere que os indícios apontados no enunciado são ainda especulações que precisariam ser comprovadas pela ciência.

Outra estratégia utilizada pelo jornal para incorporar vozes científicas consiste no relato de pesquisa em andamento. Nestes casos, a centralidade do enunciado está na ação dos centros de pesquisa e pesquisadores (Figura 9).

Figura 9 - Enunciados focam em ações da comunidade científica

Video: Flocruz começa testes para entender surto de microcefalia (DP, 24/11/2015)

Pesquisadores trabalham para detectar se há ligaçảo entre zika e Guillain-Barré (DP, 10/02/2016)

A ciència contra o mosquito (DP, 21/12/2015) 
Nos exemplos, o uso dos verbos "investigar" e "trabalhar" produzem sentidos de que os atores discursivos do campo científico estão empenhados em levantar dados sobre o mecanismo de funcionamento do vírus e consequências ainda não esclarecidas sobre a infecção. Posiciona-se a ciência como sujeito ativo dos enunciados, seja na figura da instituição de pesquisa Fiocruz, do sujeito coletivo "pesquisadores" ou, ainda, do sujeito abstrato "a ciência". A ciência aparece como instituição engajada no combate à epidemia, relação que fica explícita no último enunciado dos exemplos ("A ciência contra o mosquito").

\section{Cenário de Orientação}

A categoria comunicativa de Orientação reúne enunciados com informações práticas sobre estratégias de prevenção da propagação do vírus ou de identificação e tratamento dos seus sintomas. Respaldando-se no discurso científico e no discurso médico, o objetivo é o de apresentar informações sobre o vírus, a fim de evitar a divulgação de informações falsas. Classificamos esses enunciados como Orientação justamente por eles terem uma visada pragmática, fornecendo informações e orientações ao leitor de como agir. Vejamos essa categoria na Figura 10:

Figura 10 - Categoria comunicativa de Orientação

Boatos perigosos à saúde: verdades e mentiras sobre zika e microcefalia (DP, 11/12/2015)

Aedes e pernilongo: conheça as diferenças (DP, 25/02/2016)

Repelente adequado pode ser utilizado sem nenhum risco para o bebê, garante médica (DP, 30/11/2015)

Fonte: Jornal Diario de Pernambuco.

Nos exemplos, o uso da oposição entre "verdades e mentiras", na primeira manchete, e do verbo "conheça" no imperativo, na segunda, conformam um sentido de informação prática sobre Zika e microcefalia, no primeiro caso, e de como identificar o seu agente transmissor, no segundo. Na primeira manchete, o sentido de esclarecimento foi realçado pela construção textual que assume o rumor como um perigo para a saúde. A tentativa de distinguir informações corretas de boatos também aparece na última manchete, em que se usou a voz de uma fonte especializada para garantir que o uso de repelente 
em bebês é adequado. Neste caso, há uma visada explícita de orientação de ação da população em área epidêmica.

\section{Cenário de Ação}

A categoria comunicativa de Ação tem a função de informar os leitores sobre os esforços feitos pelo governo e autoridades de saúde para controlar o surto de Zika em território nacional. Mobilizam-se os discursos institucionais que narram a ação de instituições nacionais e locais para combater a epidemia, como pode ser observado na Figura 11.

Figura 11 - Categoria Comunicativa de Ação

\section{Prefeitura do Recife e exéreito definem açōes de combate ao mosquito Aedes Aegypti (DP, 02/12/2015) \\ Dilma prepara campanha de moblizaçăo nacional de combate ao zika (DP, 25/01/2016) \\ Governo encomendara 500 mil kits de testes para o virus zika (DP, 16/01/2016) \\ Prefeitura convoca 500 voluntários para combater o aedes aegypti (DP, 03/12/2015)}

Fonte: Diario de Pernambuco.

Nos exemplos, a prefeitura do Recife, o exército e o Governo Federal, representada pela presidente Dilma Rousseff, aparecem como sujeitos de ação dos enunciados. O sentido de ação produz-se pelo uso de verbos ativos no presente e futuro ("definem”, "prepara”, "encomendará", "convoca”). Essa construção discursiva pode ter um nível performativo, quando fala sobre pronunciamentos ou descreve reuniões e decisões tomadas pelas autoridades, como nos dois primeiros exemplos, em que a prefeitura do Recife e o Exército Nacional "definem ações" e a presidente Dilma "prepara campanha de mobilização nacional". Os últimos dois enunciados têm um nível mais pragmático, mostram ações concretas de combate à epidemia, como o repasse de kits de testes para o vírus da Zika pelo governo e a convocação de voluntários para combater os focos do mosquito.

Um segundo conjunto de enunciados foca nas ações realizadas junto à comunidade recifense, como os mutirões realizados pelos agentes de saúde locais para destruir os locais de reprodução do Aedes aegypti e a mobilização em escolas (Figura 12). No caso dos mutirões, indicam-se os bairros em que acontecerão as ações para que os leitores estejam avisados caso seja na sua vizinhança. 
Figura 12 - Enunciados focam em ações na comunidade

Mutirălo de combate ao aedes aegypti em três bairros neste fim de semana

(DP, 15/01/2016)

Escolas mobilizadas para o combate ao Aedes (DP, 19/02/2016)

Estudante tem o poder de multiplicar combate ao Aedes na familia e comunidade (DP, 19/02/2016)

Fonte: Diario de Pernambuco.

Apesar de narrar as ações em bairros e apontar a necessidade da comunidade se envolver com o combate ao Aedes, são poucas as fontes populares inseridas nestes enunciados. Adota-se, no seu conjunto, a voz institucional para falar sobre a epidemia. Ao focar nas ações e decisões das autoridades, tenta-se produzir um efeito de sentido de que a epidemia está sendo controlada. A proximidade de grandes eventos, como o Carnaval do Rio, em fevereiro, e as Olimpíadas, também no Rio, com começo marcado para junho de 2016 faz esse sentido de controle parecer mais urgente. Os enunciados da Figura 13 tentam minimizar os efeitos da epidemia, por meio do uso de recurso de autoridade, ou seja, vozes oficiais que legitimam a informação, e a adoção de tom de despreocupação em relação à epidemia. A comparação entre Zika e gripe e o fato de não comprometer grandes eventos produzem sentidos de que há cenários mais graves.

Figura 13 - Enunciados convocam vozes oficiais

Gripe mata mais que zika virus, diz prefeito do Rio (DP, 12/02/2016)

Zika não compromete Olimpíada no Rio, diz Dilma (DP, 13/02/2016)

Fonte: Diario de Pernambuco.

Há poucas notícias que questionam e discordem das decisões e ações das autoridades. No corpus, foram localizados apenas quatro títulos com uma abordagem crítica em relação à epidemia. Três enunciados abordam a falta de saneamento como um dos fatores agravantes no combate ao mosquito. Em um deles, a voz dos moradores, fontes populares, testemunham os problemas de saneamento nos bairros de periferia do Recife. Em outro enunciado, a fala 
de fontes especializadas reforça a necessidade de se resolver essa questão do saneamento público (Figura 14).

Figura 14 - Enunciados com abordagem crítica

Moradores reclamam de falta de saneamento em ação de combate ao mosquito da Zika (DP, 13/02/2016)

André Monteiro e Lia Giraldo defendem o saneamento contra a microcefalia $(\mathrm{DP}, 24 / 12 / 2015)$

Fonte: Diario de Pernambuco.

\section{Cenário de Consequências}

Enunciados que intentam mostrar como as pessoas atingidas estão lidando com as consequências da infecção por Zika vírus e da microcefalia. Recorrese, aqui, ao discurso popular e a histórias de vida de vítimas que lidam com essas consequências no seu cotidiano. Também vemos a presença de discursos institucionais, com declarações e posicionamentos de fontes oficiais como a Organização das Nações Unidas sobre o direito ao aborto em casos de fetos com microcefalia. Alguns enunciados tentam aproximar esses posicionamentos institucionais do leitor, incitando-o a refletir e se posicionar sobre o aborto em casos de microcefalia. Na Figura 15 trazemos exemplos dessas configurações discursivas.

Figura 15 - Exemplos da categoria comunicativa de consequência

Grupos no Whatsapp e no Facebook amparam familias de bebes com microcefalia (DP, 01/02/2016)

ONU defende direito ao aborto em paises atingidos pelo zika (DP, 05/02/2016)

Vocề é a favor do aborto em casos de microcefalia? Dom Paulo Garcia afirma que กส̆อ (DP, 14/02/2016)

Fonte: Diario de Pernambuco.

Nos exemplos, observamos um confronto entre enunciados de uma matriz discursiva religiosa e moral e de uma matriz discursiva racional e científica. sobre o aborto. A primeira é representada por Dom Paulo Garcia, que se posiciona 
contrário ao aborto em casos de microcefalia. Esse posicionamento entende que há a possibilidade de se criar uma rede de apoio comunitário para enfrentar as dificuldades. A matriz racional e científica, representada pela voz da ONU, baseia-se na escolha individual e relata o aumento de casos de abandono paterno por causa da microcefalia.

\section{Considerações finais}

Neste artigo, analisamos a construção discursiva da epidemia do vírus da Zika no jornal Diario de Pernambuco, tentando compreender qual a postura assumida pelo jornal na cobertura jornalística da epidemia. Na nossa análise, mapeamos a predominância de três configurações comunicativas nos enunciados: Alerta, Convicção Científica e Ação. Com a maior quantidade de enunciados, a categoria Alerta remete à construção de sentidos da epidemia como um fenômeno incontrolável. O uso de expressões alarmantes e as notificações de casos de microcefalia nos títulos reiteram um discurso de pânico e medo comum a outras coberturas midiáticas de epidemia, como as analisadas por Medeiros e Massarani (2010; 2011a; 2011b), Lerner e Gradella (2011).

As incertezas com relação ao cenário da epidemia proporcionaram o acionamento de vozes científicas para explicar os modos de ação e as relações encontradas entre Zika e microcefalia. Os cientistas e institutos de pesquisa são retratados como atores comprometidos com a busca por respostas, apesar destas serem frágeis nos meses iniciais da epidemia.

Esse mesmo sentido de confiança parece também guiar os enunciados que relatam a ação de autoridades e instituições no combate à epidemia. O foco em discursos e ações institucionais, em detrimento de ações populares, mostra-nos que a cobertura da epidemia feita pelo Diario de Pernambuco é pautada majoritariamente pelo conteúdo produzido pelas assessorias de imprensa de órgãos de saúde e do governo, como destaque para a Fiocruz, o Ministério da Saúde e o governo brasileiro. Diante do caos, tenta-se mostrar que a epidemia está sendo levada à sério pelas autoridades e que estas estão no controle da situação.

Nos títulos, vemos que o jornal se coloca na posição de informar a população sobre o surto e pouco explicita orientações de condutas de combate ao vetor transmissor da epidemia. Fazemos a ressalva de que nossa análise foi limitada apenas aos títulos, fornecendo indícios explícitos dessa postura. Novos estudos qualitativos focados nas matérias jornalísticas podem trazer outros apontamentos 
para essa questão, precisando em que medida essa postura associada a discursos oficiais é mantida nos textos do jornal.

\section{Referências}

AGUIAR, Raquel; ARAUJO, Inesita. A mídia em meio às 'emergências' do vírus Zika: questões para o campo da comunicação e saúde. RECIIS - Revista Eletrônica Comunicação Informação Inovação em Saúde, Rio de Janeiro, v. 10, n. 1, p. 1-15, 2016. Disponível em: https://www.reciis.icict.fiocruz.br/index.php/reciis/article/view/ 1088. Acesso em: 2 nov. 2018. https://doi.org/10.29397/reciis.v10i1.1088

BENETTI, Márcia. Jornalismo e perspectivas de enunciação: uma abordagem metodológica. Revista Intexto, Porto Alegre, UFRGS, v. 1, n. 14, p.1-11, 2006. Disponível em: https://seer.ufrgs.br/intexto/article/view/4251. Acesso em: 2 nov. 2018.

CHARAUDEAU, Patrick; MAINGUENEAU, Dominique. Dictionnaire d'analyse du discours. Paris: Éditions du Seuil, 2002.

DIARIO DE PERNAMBUCO. Aumento dos casos de dengue, Chikungunya e zika leva a estado de emergência. Diario de Pernambuco online, Recife, 30 nov. 2015. Seção Local. Disponível em: http://www.diariodepernambuco.com.br/app/noticia/vida-urbana/2015/11/30/interna_vidaurbana,613212/aumento-dos-casos-de-dengue-chikungunya-e-zika-leva-a-estado-de-emergencia.shtml. Acesso em: 20 out. 2018.

DIARIO DE PERNAMBUCO. Ministério da Saúde faz alerta nacional por causa do surto de microcefalia em Pernambuco. Diario de Pernambuco online, Recife, 12 de nov. 2015., Seção Local. Disponível em: http://www.diariodepernambuco.com.br/app/noticia/ vida-urbana/2015/11/12/interna_vidaurbana,609734/ministerio-da-saude-faz-alerta-nacional-por-causa-do-surto-de-microcefalia-em-pernambuco.shtml. Acesso em: 20 out. 2018.

DIARIO DE PERNAMBUCO. Microcefalia: zika vírus é a causa provável. Diario de Pernambuco online, Recife, 17 nov. 2015. Seção Local. Disponível em: http://www. diariodepernambuco.com.br/app/noticia/vida-urbana/2015/11/17/interna_vidaurbana,610837/microcefalia-zika-virus-e-a-causa-provavel.shtml. Acesso em: 20 out. 2018.

DIARIO DE PERNAMBUCO. Vírus zika representa ameaça para a saúde humana, diz instituto francês. Diario de Pernambuco online, Recife, 9 jan. 2016. Seção Brasil. Disponível em: http://www.diariodepernambuco.com.br/app/noticia/brasil/2016/01/o9/ interna_brasil,620467/virus-zika-representa-ameaca-para-a-saude-humana-diz-instituto-france.shtml. Acesso em: 20 out. 2018.

DIARIO DE PERNAMBUCO. Microcefalia: OMS decreta emergência de saúde pública mundial. Diario de Pernambuco online, Recife, 3 fev. 2016. Seção Local. Disponível em: http://www.diariodepernambuco.com.br/app/noticia/vida-urbana/2016/02/03/ 
interna_vidaurbana,625148/microcefalia-oms-decreta-emergencia-de-saude-publica-mundial.shtml. Acesso em: 20 out. 2018.

DIARIO DE PERNAMBUCO. Microcefalia leva pânico ao mundo e dá margem a novas teorias sobre suas causas. Diario de Pernambuco online, Recife, 12 fev. 2016, Seção Ciência e Saúde. Disponível em: http://www.diariodepernambuco.com.br/app/noticia/ ciencia-e-saude/2016/02/12/internas_cienciaesaude,626558/cresce-o-numero-de-casos-de-microcefalia-e-teorias-sobre-possiveis-cau.shtml. Acesso em: 27 out. 2018.

DIARIO DE PERNAMBUCO. Pernambuco tem mais de 1.600 casos de microcefalia notificados. Diario de Pernambuco online, Recife, 24 fev. 2016. Seção Local. Disponível em: http://www.diariodepernambuco.com.br/app/noticia/vida-urbana/2016/02/24/ interna_vidaurbana,628786/pernambuco-chega-a-mais-de-1-600-casos-de-microcefalia-notificados.shtml Acesso em: 27 out. 2018.

DIARIO DE PERNAMBUCO. De 1 a 5 de janeiro estado do Rio registra 121 casos de microcefalia. Diario de Pernambuco online, Recife, 6 jan. 2016. Seção Brasil. Disponível em: http://www.diariodepernambuco.com.br/app/noticia/brasil/2016/01/o6/interna_brasil,619968/de-1-a-5-de-janeiro-estado-do-rio-registra-121-casos-de-microcefalia. shtml. Acesso em: 27 out. 2018.

DIARIO DE PERNAMBUCO. Zika está em praticamente toda a América Latina e Caribe, diz OPAS. Diario de Pernambuco online, Recife, 20 jan. 2016. Seção Ciência e Saúde. Disponível em:

http://www.diariodepernambuco.com.br/app/noticia/ciencia-e-saude/2016/01/20/ internas_cienciaesaude,622481/zika-esta-em-praticamente-toda-america-latina-e-caribe-diz-opas.shtml. Acesso em: 27 out. 2018.

DIARIO DE PERNAMBUCO. Sobe para 3.893 o número de casos de microcefalia no país. Diario de Pernambuco online, Recife, 20 jan. 2016. Seção Brasil. Disponível em:

http://www.diariodepernambuco.com.br/app/noticia/brasil/2016/01/20/interna_brasil,622575/sobe-para-3-893-o-numero-de-casos-de-microcefalia-no-pais.shtml. Acesso em: 27 out. 2018.

DIARIO DE PERNAMBUCO. "O que está acontecendo é inédito", diz infectologista Vicente Vaz. Diario de Pernambuco online, Recife, 25 nov. 2015. Seção Local. Disponível em: http://www.diariodepernambuco.com.br/app/noticia/vida-urbana/2015/11/25/ interna_vidaurbana,612314/o-que-esta-acontecendo-e-inedito-diz-infectologista-vicente-vaz.shtml Acesso em: 27 out. 2018.

DIARIO DE PERNAMBUCO. "É a única certeza hoje: temos de eliminar o aedes", diz pesquisador da Fiocruz. Diario de Pernambuco online, Recife, 27 dez. 2015. Seção Brasil. Disponível em: http://www.diariodepernambuco.com.br/app/noticia/brasil/2015/12/27/ 
interna_brasil,618448/e-a-unica-certeza-hoje-temos-de-eliminar-o-aedes-diz-pesquisador-d.shtml. Acesso em: 27 out. 2018.

DIARIO DE PERNAMBUCO. Zika vírus causa necrose cerebral. Diario de Pernambuco online, Recife, 28 dez. 2015. Seção Brasil. Disponível em:

http://www.diariodepernambuco.com.br/app/noticia/brasil/2015/12/28/interna_brasil,618474/zika-virus-causa-necrose-cerebral.shtml. Acesso em: 27 out. 2018.

DIARIO DE PERNAMBUCO. Além de síndrome de guillan-barré, há mais três doenças ligadas ao zika. Diario de Pernambuco online, Recife, 30 abr. 2016. Seção Local. Disponível em: http://www.diariodepernambuco.com.br/app/noticia/vida-urbana/2016/04/30/ interna_vidaurbana,642031/mais-tres-doencas-ligadas-ao-zika.shtml. Acesso em: 27 out. 2018.

DIARIO DE PERNAMBUCO. Elo entre o zika vírus e a microcefalia pode estar no cordão umbilical. Diario de Pernambuco online, Recife, 11 dez. 2015. Seção Local. Disponível em: http://www.diariodepernambuco.com.br/app/noticia/vida-urbana/2015/12/11/ interna_vidaurbana,615586/elo-entre-o-zika-virus-e-a-microcefalia-pode-estar-no-cordao-umbilical.shtml Acesso em: 27 out. 2018.

DIARIO DE PERNAMBUCO. Zika vírus é capaz de atravessar a placenta das gestantes, diz Fiocruz. Diario de Pernambuco online, Recife, 20 jan. 2016. Seção Brasil. Disponível em:

http://www.diariodepernambuco.com.br/app/noticia/brasil/2016/01/20/interna_brasil,622507/zika-virus-e-capaz-de-atravessar-a-placenta-das-gestantes-diz-fiocruz.shtml

\section{Acesso em: 27 out. 2018.}

DIARIO DE PERNAMBUCO. Fiocruz confirma presença do vírus zika em amostras de saliva e urina. Diario de Pernambuco online, Recife, 5 fev. 2016. Seção Brasil. Disponível em:

http://www.diariodepernambuco.com.br/app/noticia/vida-urbana/2016/02/05/ interna_vidaurbana,625705/fiocruz-confirma-presenca-do-virus-zika-em-amostras-de-saliva-e-urina.shtml Acesso em: 27 out. 2018.

DIARIO DE PERNAMBUCO. Danos provocados por zika em bebês são maiores do que se pensava, diz pesquisa. Diario de Pernambuco online, Recife, 26 fev. 2016. Seção Brasil. Disponível em: http://www.diariodepernambuco.com.br/app/noticia/ciencia-e-saude/2016/02/26/internas_cienciaesaude,629359/danos-provocados-por-zika-em-bebes-sao-maiores-do-que-se-pensava-diz.shtml. Acesso em: 27 out. 2018.

DIARIO DE PERNAMBUCO. Vídeo: Fiocruz começa testes para entender surto de microcefalia. Diario de Pernambuco online, Recife, 26 fev. 2016. Seção Local. Disponível em: http://www.diariodepernambuco.com.br/app/noticia/vida-urbana/2015/11/24/ interna_vidaurbana,612134/video-fiocruz-comeca-testes-para-entender-surto-de-microcefalia.shtml Acesso em: 27 out. 2018. 
DIARIO DE PERNAMBUCO. A ciência contra o mosquito. Diario de Pernambuco online, Recife, 21 dez. 2015. Seção Local. Disponível em:

http://www.diariodepernambuco.com.br/app/noticia/vida-urbana/2015/12/21/interna_vidaurbana,617525/a-ciencia-contra-o-mosquito.shtml Acesso em: 27 out. 2018.

DIARIO DE PERNAMBUCO. Pesquisadores trabalham para detectar se há ligação entre zika e guillain-barré. Diario de Pernambuco online, Recife, 10 fev. 2016. Seção Local. Disponível em: http://www.diariodepernambuco.com.br/app/noticia/ciencia-e-saude/2016/02/10/internas cienciaesaude,626322/pesquisadores-trabalham-para-detectar-se-ha-ligacao-entre-zika-e-guill.shtml. Acesso em: 27 out. 2018.

DIARIO DE PERNAMBUCO. Boatos perigosos à saúde: verdades e mentiras sobre zika e microcefalia. Diario de Pernambuco online, Recife, 11 dez. 2015. Seção Local. Disponível em: http://www.diariodepernambuco.com.br/app/noticia/vida-urbana/2015/12/11/ interna vidaurbana,615588/boatos-perigosos-a-saude-verdades-e-mentiras-sobre-zika-e-microcefalia.shtml. Acesso em: 27 out. 2018.

DIARIO DE PERNAMBUCO. Aedes e pernilongo: conheça as diferenças. Diario de Pernambuco online, Recife, 25 fev. 2016. Seção Local. Disponível em:

http://www.diariodepernambuco.com.br/app/noticia/ciencia-e-saude/2016/02/25/ internas_cienciaesaude,629135/aedes-e-pernilongo-conheca-as-diferencas.shtml. Acesso em: 27 out. 2018.

DIARIO DE PERNAMBUCO. Repelente adequado pode ser utilizado sem nenhum risco para o bebê, garante médica. Diario de Pernambuco online, Recife, 30 nov. 2015. Seção Local. Disponível em: http://www.diariodepernambuco.com.br/app/noticia/vida-urbana/2015/11/30/interna vidaurbana,612956/repelente-adequado-pode-ser-utilizado-sem-nenhum-risco-para-o-bebe-garante-medica.shtml. Acesso em: 27 out. 2018.

DIARIO DE PERNAMBUCO. Prefeitura do Recife e exército definem ações de combate ao mosquito Aedes Aegypti. Diario de Pernambuco online, Recife, 2 de dezembro de 2015, Seção Local. Disponível em:

http://www.diariodepernambuco.com.br/app/noticia/vida-urbana/2015/12/o2/ interna_vidaurbana,613661/prefeitura-do-recife-e-exercito-definem-acoes-de-combate-ao-mosquito-aedes-aegypti.shtml. Acesso em: 27 out. 2018.

DIARIO DE PERNAMBUCO. Dilma prepara campanha de mobilização nacional de combate ao zika. Diario de Pernambuco online, Recife, 25 de janeiro de 2016, Seção Brasil, Disponível em: http://www.diariodepernambuco.com.br/app/noticia/brasil/2016/01/25/ interna_brasil,623499/dilma-prepara-campanha-de-mobilizacao-nacional-de-combate-ao-zika.shtml. Acesso em: 27 out. 2018.

DIARIO DE PERNAMBUCO. Governo encomendará 500 mil kits de testes para o vírus zika. Diario de Pernambuco online, Recife, 16 de janeiro de 2016, Seção Brasil, Disponível 
em: http://www.diariodepernambuco.com.br/app/noticia/brasil/2016/01/16/interna_brasil,621865/governo-encomendara-500-mil-kits-de-testes-para-o-virus-zika. shtml. Acesso em: 27 out. 2018.

DIARIO DE PERNAMBUCO. Prefeitura convoca 500 voluntários para combater o aedes aegypti. Diario de Pernambuco online, Recife, 3 dez. 2015. Seção Local, Disponível em: http://www.diariodepernambuco.com.br/app/noticia/vida-urbana/2015/12/03/ interna_vidaurbana,614096/prefeitura-convoca-500-voluntarios-para-combater-o-aedes-aegypti.shtml. Acesso em: 27 out. 2018.

DIARIO DE PERNAMBUCO. Mutirão de combate ao aedes aegypti em três bairros neste fim de semana. Diario de Pernambuco online, Recife, 15 jan. 2016. Seção Local. Disponível em: http://www.diariodepernambuco.com.br/app/noticia/vida-urbana/2016/01/15/ interna_vidaurbana,621761/mutirao-de-combate-ao-aedes-aegypti-em-tres-bairros-neste-fim-de-seman.shtml. Acesso em: 27 out. 2018.

DIARIO DE PERNAMBUCO. Escolas mobilizadas para o combate ao Aedes. Diario de Pernambuco online, Recife, 19 fev. 2016. Seção Local, Disponível em:

http://www.diariodepernambuco.com.br/app/noticia/vida-urbana/2016/02/19/interna_vidaurbana,627865/escolas-mobilizadas-para-o-combate-ao-aedes.shtml. Acesso em: 27 out. 2018.

DIARIO DE PERNAMBUCO. Estudante tem o poder de multiplicar combate ao Aedes na família e comunidade. Diario de Pernambuco online, Recife, 19 fev. 2016. Seção Local, Disponível em: http://www.diariodepernambuco.com.br/app/noticia/vida-urbana/2016/02/19/interna_vidaurbana,627958/estudante-tem-o-poder-de-multipilicar-combate-ao-aedes-na-familia-e-co.shtml. Acesso em: 27 out. 2018.

DIARIO DE PERNAMBUCO. Gripe mata mais que zika vírus, diz prefeito do Rio. Diario de Pernambuco online, Recife, 12 fev. 2016. Seção Brasil. Disponível em: http://www. diariodepernambuco.com.br/app/noticia/brasil/2016/02/12/interna_brasil,626718/ gripe-mata-mais-que-zika-virus-diz-prefeito-do-rio.shtml. Acesso em: 27 out. 2018.

DIARIO DE PERNAMBUCO. Zika não compromete Olimpíada no Rio, diz Dilma. Diario de Pernambuco online, Recife, 13 fev. 2016. Seção Brasil, Disponível em: http://www. diariodepernambuco.com.br/app/noticia/brasil/2016/02/13/interna_brasil,626838/ zika-nao-compromete-olimpiada-no-rio-diz-dilma.shtml. Acesso em: 27 out. 2018.

DIARIO DE PERNAMBUCO. Moradores reclamam de falta de saneamento em ação de combate ao mosquito da Zika. Diario de Pernambuco online, Recife, 13 fev. 2016. Seção Local. Disponível em:

http://www.diariodepernambuco.com.br/app/noticia/vida-urbana/2016/02/13/ interna_vidaurbana,626835/moradores-reclamam-de-falta-de-sanemento-em-acao-de-combate-ao-mosquit.shtml. Acesso em: 27 out. 2018. 
DIARIO DE PERNAMBUCO. André Monteiro e Lia Giraldo defendem o saneamento contra a microcefalia. Diario de Pernambuco online, Recife, 24 dez. 2015. Seção Local, Disponível em: http://www.diariodepernambuco.com.br/app/noticia/politi$\mathrm{ca} / 2015 / 12 / 24 /$ interna_politica,618035/andre-monteiro-e-lia-giraldo-defendem-o-saneamento-contra-a-microcefal.shtml. Acesso em: 27 out. 2018.

DIARIO DE PERNAMBUCO. Grupos no Whatsapp e no Facebook amparam famílias de bebês com microcefalia. Diario de Pernambuco online, Recife, 1 fev. 2016. Seção Local, Disponível em:

http://www.diariodepernambuco.com.br/app/noticia/vida-urbana/2016/02/01/interna_vidaurbana,624688/grupos-no-whatsapp-e-no-facebook-amparam-familias-de-bebes-com-microc.shtml. Acesso em: 27 out. 2018.

DIARIO DE PERNAMBUCO. ONU defende ao aborto em países atingidos pelo zika. Diario de Pernambuco online, Recife, 5 fev. 2016. Seção Brasil., Disponível em:

http://www.diariodepernambuco.com.br/app/noticia/brasil/2016/02/05/interna_brasil,625751/onu-defende-direito-ao-aborto-em-paises-atingidos-pelo-zika.shtml. Acesso em: 27 out. 2018.

DIARIO DE PERNAMBUCO. Você é a favor do aborto em casos de microcefalia? Dom Paulo Garcia afirma que não. Diario de Pernambuco online, Recife, 14 fev. 2016., Seção Local, Disponível em: http://www.diariodepernambuco.com.br/app/noticia/politica/2016/02/14/interna_politica,626919/voce-e-a-favor-do-aborto-em-casos-de-microcefalia-dom-paulo-garcia-a.shtml. Acesso em: 27 out. 2018.

FARIAS, Eduardo. Jornalismo à Espanhola: um olhar sobre o noticiário recifense da epidemia de gripe de 1918. 2008. 179 f. Dissertação (Mestrado em Comunicação) Programa de Pós-Graduação em Comunicação, UFPE, Pernambuco, 2008.

FERRAZ, Luiz Marcelo; GOMES, Isaltina. Disease as enemy: Journalistic discourse analysis about dengue fever. International Journal of Literature and Arts, [S. I.], v. 2, n. 6-1, p. 23-29, 2015. Disponível em: http://www.sciencepublishinggroup.com/journal/ paperinfo.aspx?journalid $=502 \&$ doi $=10.11648 /$ j.jila.s.2014020601.14. Acesso em: 2 nov. 2018. https://doi.org/10.11648/j.ijla.s.2014020601.14

FERRAZ, Luiz Marcelo; GOMES, Isaltina. A construção discursiva sobre a dengue na mídia. Revista Brasileira de Epidemiologia, São Paulo, v. 15, n. 1, p. 63-74, 2012. Disponível em: http://www.scielo.br/scielo.php?script=sci_abstract\&pi$\mathrm{d}=$ S1415-790X2012000100006\&lng=pt\&nrm=iso. Acesso em: 2 nov. 2018. https://doi. org/10.1590/S1415-790X2012000100006

FONSECA, Natália; GOMES, Isaltina. Dialogismo e vozes discursivas na cobertura de saúde: leituras do Bom Dia Pernambuco. In: PESSONI, Arquimedes (org.). Comunicação, 
Saúde e Pluralidade: novos olhares e abordagens em pauta. São Caetano do Sul: USCS, 2015. Série Comunicação \& Inovação, v. 6, p.86-101.

GOMES, Isaltina, SILVA, Amanda; FEITOZA, Liliane. Zika vírus: divulgação científica e relevância jornalística. In: CONGRESO DE LA ASOCIACIÓN LATINOAMERICANA DE INVESTIGADORES DE LA COMUNICACIÓN (ALAIC), 14., 2018,. Anais [ ...]. San JoseCosta Rica, 2018.

LERNER, Kathia; GRADELLA, Pedro. Mídia e pandemia: os sentidos do medo na cobertura de Influenza $\mathrm{H}_{1} \mathrm{~N}_{1}$ nos jornais cariocas. Eco (UFRJ), Rio de Janeiro, v. 14, p. 33-54, 2011. Disponível em: https://revistas.ufrj.br/index.php/eco_pos/article/view/1204. Acesso em: 2 nov. 2018.

MAINGUENEAU, Dominique. Analyser les textes de communication. Paris: Armand Colin, 2014.

MAINGUENEAU, Dominique. Gênese dos discursos. São Paulo: Parábola Editorial, 2008.

MEDEIROS, Flávia; MASSARANI, Luisa. La cobertura de la gripe A ( $\left.\mathrm{H}_{1} \mathrm{~N}_{1}\right) 2009$ en Brasil: un estúdio de caso con el Jornal Nacional. In: CEVALLOS, Maria del Carmen; MASSARANI, Luisa (ed.). La pandemia del miedo: Telediarios y la gripe A ( $\left.\mathrm{H}_{1} \mathrm{~N}_{1}\right)$ en Ecuador y Brasil. Quito: 2011a.

MEDEIROS, Flávia; MASSARANI, Luisa . A cobertura da gripe A ( $\left.\mathrm{H}_{1} \mathrm{~N}_{1}\right) 2009$ pelo Fantástico. Intercom - Revista Brasileira de Ciências da Comunicação, São Paulo, v. 34, n. 1, p. 41-59, jan./jun. 2011b. Disponível em: http://www.scielo.br/scielo.php?pi$\mathrm{d}=\mathrm{S} 1809-58442011000100003 \&$ script=sci_abstract Acesso em: 2 nov. 2018. https:// doi.org/10.1590/S1809-58442011000100003

MEDEIROS, Flávia; MASSARANI, Luisa. Pandemic on the air: a case study on the coverage of new influenza $A / \mathrm{H}_{1} \mathrm{~N}_{1}$ by Brazilian prime time TV news, Journal of Science Communication (JCOM), [S. l.], v. 9, n. 3, p. 1-9, 2010. Disponível em: https://jcom. sissa.it/archive/09/03/Jcomo903\%282010\%29A03 Acesso em: 2 nov. 2018. https:// doi.org/10.22323/2.09030203

PRAZERES, Giselle; LIMA, Irenilda; MACIEL, Betania. Mídia e divulgação de conhecimentos sobre as doenças transmitidas pelo mosquito Aedes aegypti em Recife - Pernambuco, Razón y Palabra, [S. l.], v. 20, n. 4-95, 2016, p. 3-25. Disponível em: http://www.revistarazonypalabra.org/index.php/ryp/article/view/79o Acesso em: 2 nov. 2018.

ORLANDI, Eni. Análise de discurso: princípios e procedimentos. Campinas: Pontes, 2002.

SHIH, Tsung-Jen; WIJAYA, Rosalyna; BROSSARD, Dominique. Media Coverage of Public Health Epidemics: linking framing and issue attention cycle toward an integrated theory of print News coverage of Epidemics, Mass Communication and Society, [S. l.], v.11, n. 2, p. 141-160, 2008. Disponível em: https://www.tandfonli- 
ne.com/doi/abs/10.1080/15205430701668121. Acesso em: 2 nov. 2018. https://doi. org/10.1080/15205430701668121

\section{Dados da autora:}

\section{Natalia Martins Flores - nataliflores@gmail.com}

Pós-Doutora em Comunicação pela Universidade Federal de Santa Maria (UFSM), Doutora em Comunicação na Universidade Federal de Pernambuco (UFPE).

Membro do grupo de pesquisa Comunicação e Linguagem (PPGCOM/UFPE)

\section{Endereço da autora:}

Programa de Pós-Graduação em Comunicação, Universidade Federal de Pernambuco - Av. Prof. Moraes Rego, 1235 - Cidade Universitária - Recife (PE), Brasil

\section{Dados da autora:}

Isaltina Maria de Azevedo Mello Gomes - isaltina@gmail.com

Doutora em Linguística pela Universidade Federal de Pernambuco. Docente e pesquisadora do Programa de Pós-Graduação em Comunicação da UFPE.

\section{Endereço da autora:}

Programa de Pós-Graduação em Comunicação, Universidade Federal de Pernambuco - Av. Prof. Moraes Rego, 1235 - Cidade Universitária , Recife (PE) - Brasil 